\title{
KECENDERUNGAN MINAT MAHASISWA PROGRAM STUDI KOMUNIKASI DAN PENYIARAN ISLAM (KPI) TERHADAP PROFESI JURNALIS
}

\author{
Hotna Sari $^{1}$; Heri Rahmatsyah Putra ${ }^{2}$ \\ STAI Ar-Ridho Bagansiapiapi ${ }^{1}$; STAIN Teungku Dirundeng Meulaboh ${ }^{2}$ \\ E-mail: hotnasari703@gmail.com; herirahmatsyahputra@staindirundeng.ac.id
}

\begin{abstract}
Abstrak
Penelitian ini bertujuan untuk mengetahui kecenderungan minat mahasiswa Program Studi Komunikasi dan Penyiaran Islam STAI Ar-Ridho Bagansiapiapi terhadap profesi jurnalis. Metode yang dipakai dalam penelitian ini ialah metode deskritif kuantitatif dengan analisis data melalui perhitungan data statistik sederhana. Teknik pengumpulan data menggunakan panduan observasi, interview, panduan kuisioner dan dokumentasi. Hasil dari penelitian menunjukkan bahwa faktor yang mempengaruhi kecenderungan minat mahasiswa Program Studi Komunikasi dan Penyiaran Islam terhadap profesi Jurnalis, terdapat faktor individu (Interpersonal) yang terdiri dari empat indikator, yaitu indikator keseriusan terhadap profesi jurnalistik, kemauan, sikap, dan keaktifan dalam melakukan atau mengikuti perkuliahan jurnalistik di program Studi Komunikasi dan Penyiaran Islam memiliki jumlah presentase sebesar 59.07\%, dari empat indikator tersebut dengan rata-rata jumlah jawaban tiap pernyatan sebanyak 62.96. Sedangkan faktor lingkungan terbagi menjadi tiga indikator yaitu peduli, kesenangan, dan intensitas dalam mempelajari atau yang dilakukan memiliki presentase sebesar $36.35 \%$ dengan rata-rata jumlah jawaban tiap pernyataan sebesar 37.03. Kesimpulan hasil penelitian menunjukkan bahwa kecenderungan minat mahasiswa Progam Studi Komunikasi Dan Penyiaran Islam terhadap profesi jurnalis, 84 mahasiswa memiliki kecenderungan yang tinggi terhadap profesi jurnalis.
\end{abstract}

Kata Kunci: Kecenderungan Minat Mahasiswa, Profesi Jurnalis.

\begin{abstract}
This study aims to determine the tendency of students in the study program on Islamic communication and broadcasting STAI Ar-Ridho Bagansiapiapi to the profession of journalists. The method used in this study is the quantitative descriptive method with data analysis through a simple calculation of statistical data. Data collection techniques using observation guides, interviews, questionnaire guides and documentation. The results showed that the factors that influence the tendency of students from the Islamic Program for communication and broadcasting studies to the profession of journalists, there are individual (interpersonal) factors consisting of four indicators, namely indicators of the seriousness of the profession of journalism, will, attitude and activity in the conduct or follow-up of journalistic lectures in the Programme for communication studies and broadcasting of Islam has a percentage of 59.07\%, of the four indicators with an average number of answers per question up to 62.96. Although environmental
\end{abstract}


factors are divided into three indicators, namely care, pleasure and intensity in learning or driving has a percentage of $36.35 \%$ with an average number of responses per report of 37.03. The findings showed that the tendency of students of the Islamic Program for Communication and Broadcasting Studies towards the profession of journalist, 84 students have a strong tendency to the profession of journalists.

Keywords: Student Interest Tendencies, Journalist Profession.

\section{PENDAHULUAN}

Kebutuhan manusia terhadap informasi telah merubah tatanan peradaban menjadi masyarakat yang bergantung kepada media. Kecanggihan teknologi turut mendukung kemudahan manusia dalam memperoleh segala informasi yang dikehendaki. Dunia yang secara bertahap memasuki era informasi, menjadikan peran profesi jurnalistik-pers dalam masyarakat menjadi sangat penting, sama kedudukannya dengan peran yang dimainkan oleh para ilmuan, cendikiawan dan para ulama. Posisi peran jurnalis dalam mencari, memburu, menggali serta mengolah informasi yang kemudian menyebarkan ke tengah-tengah masyarakat luas, merupakan salah satu pilar sistem pendidikan. ${ }^{1}$ Seperti halnya di Indonesia, media tumbuh dan berkembang dengan begitu cepat. Dimulai sejak perkembangan media cetak (seperti surat kabar, koran, majalah) sampai media elektronik yang banyak diminati masyarakat. Media massa sendiri memiliki andil cukup besar dalam membangun budaya di tengah masyarakat, termasuk dalam budaya kerukunan beragama. Dalam kurun waktu 10 tahun, industri media yang ada di Indonesia menunjukkan pertumbuhan yang pesat. Menurut Bagir Manan berdasarkan data yang dilaporkan Serikat Penerbit Surat Kabar (sekarang Serikat Perusahan Pers) hampir tiap tahunnya tiras surat kabar menunjukkan pertumbuhan. Begitu pula dengan perkembangan radio, TV diikuti kemudian dengan hadirnya media berita online, juga menunjukkan tren pertumbuhan yang sama. Sekira tahun 1998, tercatat hanya terdapat 850 stasiun radio. Namun, setelah 10 tahun periode kemudian Departemen Komunikan dan Informatika melaporkan sampai 2.425 permohonan Izin Penyelenggaran Penyiaran (IPP). ${ }^{2}$

${ }^{1}$ Asep Syamsul M. Romli, Jurnalistik Praktis, (Bandung: Remaja Rosdakarya, 2005), 129.

${ }^{2}$ Abdul Manan, Upah Layak Jurnalis, Survey Upah Layak AJI di 16 Kota di Indonesia, (Jakarta: Aliansi Jurnalis Independen (AJI) Indonesia, 2011), 7. 
Kondisi ini tentu berimbas pada kebutuhan tenaga kerja di bidang industri media. Bila ditinjau taraf pendidikan jurnalis saat ini, sudah banyak ditawarkan di perguruan tinggi, dikarenakan peminatnya juga semakin banyak. Kesadaran yang tumbuh akan pentingnya bidang komunikasi menyebabkan program studi ilmu komunikasi semakin dilirik oleh masyarakat. Salah satu bagian dari komunikasi ada konsenterasi jurnalistik. Jurnalistik merupakan suatu rangkaian kegiatan dalam aktivitas komunikasi dengan cara menyebarkan atau menyiarkan berita ataupun usulannya terhadap berbagai kejadian sehari-hari atau berbagai peristiwa yang umum dan aktual dalam waktu yang secepat-cepatnya. ${ }^{3}$ Jurnalis memiliki kewajiban-kewajiban yang tidak bisa diabaikan. Kewajiban-kewajiban ini merupakan alat kontrol sosial dan pembaharuan masyarakat. Jurnalis juga berkedudukan sebagai penyalur aspirasi, pendapat dan ktirik, peran jurnalis adalah sebagai agen perubahan sosial yang mempunyai tugas-tugas penunjang pembangunan sebagai salah satu tempat terjadinya pembaharuan dan perubahan sosial.

Sementara itu program studi Komunikasi dan Penyiaran Islam pada Sekolah Tinggi Agama Islam (STAI) Ar-Ridho Bagansiapiapi dalam proses belajar mengajarnya tentu menekankan pada pembentukan sarjana muslim yang profesional dalam bidang keilmuan komunikasi baik yang akan terjun di media cetak maupun elektronik. Untuk menjadi seorang jurnalis professional tentu saja membutuhkan segala sesuatu yang mendukung ke arah tersebut seperti skill, wawasan yang luas serta minat yang dengan itu dapat menumbuhkan skill melalui latihan yang datang dari minat yang kuat, karena segala sesuatu pekerjaan harus didasari dengan adalnya minat termasuk profesi jurnalis, hal ini dapat menghasilkan informasi yang berkualitas apabila seorang jurnalis memiliki minat yang kuat di bidang jurnalistik, maka tidak heran seorang jurnalis adalah seorang yang dapat menjadi agen perubahan dalam negara. Selain itu juga menambah wawasan untuk dapat menemukan dan menggali informasi dengan benar dan sedalam-dalamnya melalui berbagai sumber baik berupa buku-buku yang berhubungan dengan kejurnalisan, berbagai macam media baik media cetak maupun media elektronik. Kemudian pelaku media seperti pemimpin redaksi, redaktur, jurnalis, atau reporter

\footnotetext{
${ }^{3}$ Djoenasih S. Sunarjo, Pengantar Ilmu Komunikasi, (Jakarta: Liberty, 2000), 8.
} 
disebut sebagai profesi. Seperti juga dokter, pengacara, akuntan, dan pendeta, profesi wartawan adalah profesi yang bukan sekedar mengandalkan keterampilan seorang tukang. Jurnalis adalah profesi yang cara kerja, watak serta semangatnya berbeda dengan seorang tukang. Oleh karena itu, masyarakat memandang jurnalis sebagai professional.

Namun setelah dicermati, dari situasi, kondisi, pertumbuhan industri media saat ini, belum menempatkan kesejahteraan profesi ini seutuhnya. Jika media dan tiras pada kurun waktu 10 tahun ini ada peningkatan signifikan, lain halnya dengan kesejahteraan jurnalis masih jauh dari harapan. Aspek penyebabnya ada beberapa hal, salah satunya adalah longgarnya regulasi dalam pendirian media, menjadikan setiap orang dapat masuk dibisnis media walaupun dengan modal pas-pasan. Media yang bermodal minim, biasanya meminta permakluman dengan tidak memberi kesejahteraan yang layak pada pekerjanya, termasuk merosotnya kesejahteraan jurnalis. Setidaknya itulah yang ditunjukkan dari hasil laporan survei Aliansi Jurnalis Indonesia (AJI). ${ }^{4}$ Ini tentu menjadi ironi, sebagai garda terdepan dari industri media, namun nasib jurnalis belum mendapat perhatian khusus dari pelaku industri media. Apalagi jika mengingat beban undang-undang yang melekat kepada pekerja media, yaitu menjadi alat kontrol sosial, jurnalis juga menjalankan fungsi pendidikan dan hiburan, bila kesejahteraan tergerus, dikuatirkan akan bermuara pada kualitas informasi yang disajikan. Dengan beban tanggungjawab yang besar sangatlah pantas jika ada tuntutan bahwa kesejahteraan wartawan perlu diberi bobot yang sepadan. Maka dari itu penulis ingin meneliti seberapa tinggi kecenderungan minat mahasiswa mahasiswa Program Studi Komunikasi Penyiaran Islam terhadap profesi Jurnalis.

\section{KONSEP TEORI}

\section{Menumbuhkan Minat}

Menurut pendapat yang diungkapkan Abdul Rahman Shaleh serta Muhbib Abdul Wahab dalam bukunya yang berjudul Psikologi dalam Persperktif Islam mengatakan secara sederhana minat dapat diartikan sebagai suatu kecenderungan

${ }^{4}$ Winurantho, Masih Bertumpu Pada Sang Pelopor, Survei Serikat Pekerja di Perusahaan Media, (Jakarta: Aliansi Jurnalis Independen Indonesia, 2010), 7. 
untuk memberikan perhatian dan bertindak terhadap orang, aktivitas atau situasi yang menjadi objek dari minat tersebut dengan disertai dengan perasaan senang. Dalam batasan tersebut terkandung suatu pengertian bahwa di dalam minat ada pemusatan perhatian objek, ada usaha (untuk mengetahui/memiliki/menguasai) dari subjek yang dilakukan dengan perasaan senang, ada daya penarik dari objek. ${ }^{5}$ Siti Maisaroh dalam skripsinya yang berjudul Pengaruh Minat Mahasiswi Fakultas Ilmu Pendidikan Universitas Negeri Medan terhadap kegiatan Dakwah Hijbut Tahrir mengatakan minat adalah salah satu faktor ketertarikan dan perhatian individu pada sesuatu objek yang menimbulkan usaha yang gigih dan serius kemudian ikut berpartisipasi dalam suatu aktivitas objek tersebut. ${ }^{6}$ Jika diamati dari kutipan konsep-konsep diatas, cukup banyak faktor-faktor yang bisa mempengaruhi timbulnya minat terhadap sesuatu, dimana secara garis besar dapat dikelompokkan menjadi dua yaitu yang bersumber dari dalam diri individu yang bersangkutan, misalnya bobot, umur, jenis kelamin, pengalaman, perasaan mampu, kepribadian, dan yang berasal dari luar mencakup lingkungan keluarga, lingkungan sekolah, dan lingkungan masyarakat.

Faktor lingkungan justru mempunyai pengaruh lebih besar terhadap timbul dan perkembangannya minat seseorang. Manakah dari ketiga macam lingkungan itu yang lebih berpengaruh? Ini sangat sulit untuk menentukannya karena ada minat seseorang timbul dan berkembangnya lebih dipengaruhi oleh faktor keluarga, tetapi ada juga dari lingkungan sekolah atau masyarakat atau sebaliknya. Di samping itu juga karena objek dari minat itu sendiri sangat banyak sekali macamnya.

Pendapat Crow and Crow menjelaskan, ada tiga faktor yang menjadi timbulnya minat, yaitu:

a. Seperti dorongan yang muncul dari diri individu, misalnya dorongan untuk makan. Dorongan kebutuhan untuk makan akan membangkitkan minat seseorang untuk bekerja atau berusaha mencari penghasilan, minat terhadap produksi makanan dan lain sebagainya. Dorongan ingin tahu dapat membangkitkan minat untuk, belajar, menuntut ilmu, melakukan

\footnotetext{
5 Abdul Rahman Saleh dan Muhbib Abdul Wahab, Psikologi Suatu Pengantar Dalam Perspektif Islam, (Jakarta: Prenada Media, 2004), 262-263.

${ }^{6}$ Siti Maisaroh, Pengaruh Minat Mahasiwi Fakultas Ilmu Pendidikan Universitas Negeri Medan Terhadap Kegiatan Dakwah Muslimah Hizbut Tahrir, ( Skripsi: 2011), 27.
} 
penelitian, dan lain-lainnya. Begitu juga minat memiliki pakaian, kosmetik dan lain sebagainya.

b. Motif sosial, dapat menjadi faktor yang membangkitkan minat untuk melakukan sesuatu aktivitas tertentu. Misalnya minat terhadap pakaian, timbul karena ingin mendapat persetujuan atau penerimaan dan perhatian orang lain. Minat untuk belajar atau menuntut ilmu pengetahuan timbul karena ingin mendapat penghargaan dari masyarakat, karena biasanya yang memiliki ilmu pengetahuan cukup luas (orang pandai) mendapat kedudukan yang tinggi dan terpandang dalam masyarakat.

c. Faktor emosional, dikarenakan minat mempunyai hubungan yang erat dengan emosi. Jika seseorang mendapatkan kesuksesan dari aktivitas yang dilakukan, akan memunculkan perasaan senang, sehingga perihal tersebut mendorong serta memperkuat minat seseorang terhadap aktivitasnya, namun sebaliknya jika suatu kegagalan yang berlaku, maka akan menghilangkan/ berdampak kepada minatnya.

Oleh karenanya, kepribadian manusia itu bersifat kompleks, sehingga sering ketiga faktor tersebut, menjadi penyebab timbulnya minat yang tidak berdiri sendiri, melainkan merupakan suatu perpaduan dari ketiga faktor tersebut, akhirnya menjadi agak sulit bagi kita untuk menentukan faktor manakah yang menjadi awal penyebab timbulnya suatu minat. ${ }^{7}$

\section{Macam-Macam Minat}

Minat dapat digolongkan dari beberapa macam, tergantung pada sudut pandang serta cara penggolongannya. Misalnya berdasarkan dari timbulnya minat, arah minat, dan dari cara mendapatkan atau mengungkapkan minat itu sendiri.

a. Berdasarkan timbulnya, minat dapat dibedakan menjadi minat primitif dan minat kultural. Minat primitif adalah minat yang timbul karena kebutuhan biologis atau jaringan-jaringan tubuh, misalnya kebutuhan akan makanan, perasaan enak atau nyaman, kebebasan beraktivitas. Minat kultural atau minat sosial, adalah minat yang timbulnya karena

7 Abdul Rahman Saleh dan Muhbib Abdul Wahab, Psikologi Suatu Pengantar Dalam Perspektif Islam, (Jakarta: Prenada Media, 2004), 263-265. 
proses belajar. Minat tidak secara langsung berhubungan dengan diri kita. Contoh minat belajar, individu punya pengalaman bahwa masyarakat atau lingkungan akan lebih menghargai orang-orang terpelajar dan pendidikan yang tinggi, sehingga hal itu akan menimbulkan minat individu untuk belajar dan berprestasi agar mendapat penghargaan dari lingkungan, hal ini mempunyai arti yang sangat penting bagi harga dirinya.

b. Berdasarkan arahnya, minat bisa dibedakan menjadi minat intrinsik dan ekstrinsik. Minat intrinsik adalah minat yang langsung berhubungan dengan aktivitas itu sendiri, ini merupakan minat yang lebih mendasar atau minat asli. Contoh seseorang belajar karena memang pada ilmu pengetahuan atau karena memang senang membaca, bukan karena ingin mendapatkan pujian atau penghargaan. Minat eksterinsik adalah minat yang berhubungan dengan tujuan akhir dari kegiatan tersebut, apabila tujuannya sudah tercapai ada kemungkinan minat tersebut hilang. Sebagai contoh ketika seseorang belajar dengan tujuan agar menjadi juta kelas atau lulus ujian. Setelah menjadi juara kelas atau ujian minat belajarnya menjadi turun.

c. Berdasarkan cara mengungkapkan minat, ini dapat dibedakan menjadi empat diantaranya:

1) Expressed interest adalah minat yang diungkapkan dengan cara meminta kepada subyek untuk menyatakan atau menuliskan kegiatan-kegiatan baik yang berupa tugas maupun bukan tukas yang disenangi dan paling tidak disenangi. Dari jawabannya dapatlah diketahui minatnya.

2) Manifest interest adalah minat yang diungkapkan dengan cara mengobservasi atau melakukan pengamatan secara langsung terhadap aktifitas-aktifitas yang dilakukan subyek atau dengan mengetahui hobbinya.

3) Tested interest adalah minat yang diungkapkan cara menyimpulkan dari hasil jawaban tes objektif yang diberikan, 
nilai-nilai yang tinggi pada suatu objek atau masalah biasanya menunjukkan minat yang tinggi pula terhadap hal tersebut.

4) Inventoried interest adalah minat yang diungkapkan dengan menggunakan alat-alat yang sudah distandardisasikan, dimana biasanya berisi pertanyaan-pertanyaan yang ditujukan kepada subjek apakah ia senang atau tidak senang terhadap sejumlah aktivitas atau sesuatu objek yang ditanyakan. ${ }^{8}$

\section{Jurnalis}

\section{a. Pengertian Jurnalis}

Jurnalis atau wartawan adalah orang yang secara teratur menuliskan berita berupa laporan dan tulisannya dikirimkan/ dimuat di mesia massa secara teratur. Laporan ini lalu dapat dipublikasikan dalam media massa, seperti koran, televisi, radio, majalah, film dokumentasi, dan internet. Wartawan mencari sumber untuk ditulis dalam laporan dan diharapkan untuk menulis laporan yang paling objektif dan tidak memiliki pandangan dari sudut tertentu untuk melayani masyarakat.

Jurnalis ialah seorang penulis atau bisa dikatakan sebagai wartawan yang berusaha memperoleh informasi berupa fakta, aktual, menarik, dan komunikatif. Dengan adanya jurnalis akan mudah menyampaikan sebuah berita hangat. Semakin berkembangnya penggunaan media massa dalam penyebaran informasi terhadap masyarakat, menjadikan keberadaan jurnalis sangat dibutuhkan. ${ }^{9}$

Berdasarkan dari pemahaman diatas, maka dapat dikatakan jurnalis berkedudukan sebagai penyalur inspirasi, pendapat dan kritik. Peran jurnalis sebagai agen perubahan sosial yang mempunyai tugas-tugas penunjang pembangunan sebagai salah satu tempat terjadinya pembaharuan dan perubahan sosial.

b. Tugas-Tugas Jurnalis

Adapun tugas dari seorang Jurnalis adalah sebagai berikut:

8 Abdul Rahman Saleh dan Muhbib Abdul Wahab, Psikologi Suatu Pengantar Dalam Perspektif Islam, (Jakarta: Prenada Media, 2004), 268.

${ }^{9}$ Asti Dewi Astari, Skripsi Minat Menjadi Jurnalis Pada Mahasiswa Komunikasi Dan Penyiaran Islam Fakultas Dakwah UIN Sunan Kalijaga Yogyakarta,http://digilib.uin-suka.ac.id.Pdf diakses pada 27 Februari 2016 
1) Jurnalis bertugas memberi contoh pandangan-pandangan masyarakat yang dilayaninya sehingga masyarakat bisa mengetahui peristiwaperistowa yang terjadi didalam belahan bumi sekitarnya atau tempattempat yang jauh.

2) Jurnalis harus bisa menarik perhatian umum dengan pesan-pesan yang diembannya sehingga pesan-pesan yang diperlukan dalam perilaku sosial bisa masuk kedalam benak pendukungnya.

3) Jurnalis harus bisa menumbuhkan suatu inspirasi dengan inspirasi masyarakat yang ditempai akan lebih mudah bisa mencontoh dan akhirnya bisa berkreasi sehingga bisa meningkatkan taraf hidup masyarakat.

4) Jurnalis harus bisa membuat suasana kemajuan pada masyarakat pendukungnya dengan cakrawala pengetahuan yang diperolehnya dari kegiatan jurnalistik atau hasil sehingga masyarakat berwawasan kedepan. ${ }^{10}$

\section{c. Jurnalis Sebagai Profesi}

Pekerjaan seperti pemimpin redaksi, redaktur, jurnalis, atau reporter disebut sebagai profesi. Seperti juga dokter, pengacara, akuntan, dan pendekat. Profesi wartawan adalah profesi yang bukan sekedar mengandalkan keterampilan seorang tukang. Jurnalis adalah profesi yang watak, semangat dan cara kerjanya berbeda dengan seorang tukang. Oleh karena itu, masyarakat memandang jurnalis sebagai professional.

Redaksi juga mempunyai tugas yang menarik. Dewasa ini redaksi yang harus membuat keputusan segera menghadapi berbagai masalah penting dimana beribu-beribu bahkan berjuta-juta orang akan membacanya. Redaksi membuat keputusan tentang berita yang perlu diliput dan berita mana yang harus dimuat. Mereka harus menilai berita mana yang akan menarik perhatian pembaca. ${ }^{11}$ Sebagai suatu profesi, dunia jurnalistik dilakukannya sebagai suatu pekerjaan yang menarik dan penuh tantangan. Pekerjaan tersebut menarik karena profesi wartawan kini telah jauh berubah dibanding ketika dunia itu pertama kali lahir. Secara ekonomis

\footnotetext{
${ }^{10}$ Muhammad Mufid, Komunikasi Regulasi dan Penyiar, (Jakarta: Kencana, 2007), 19.

${ }^{11}$ M.L. Stein, Bagaimana Menjadi Wartawan, (Jakarta: Rineka Cipta, 1993), 48.
} 
dunia wartawan telah menghantarkan setiap personal yang terlibat didalamnya kepada kehidupan yang layak, hidup sebagai anggota masyarakat yang diperhitungkan. Oleh karena itu, tantangan karena pekerjaan ini tidak bisa dilakukan tanpa memiliki keahlian khusus untuk melakukannya secara professional. Inilah alasannya wartawan/jurnalis dinilai sebagai profesi, karena aktivitasnya terikat kode etik dan kriteria. ${ }^{12}$ Kemerdekaan Pers merupakan sarana pemenuhan hak asasi manusia, yaitu hak berkomunikasi dan memperoleh informasi. Untuk mewujudkan kemerdekaan pers, wartawan Indonesia perlu menyadari adanya tanggung jawab sosial yang tercermin melalui pelaksanaan kode etik profesi. $^{13}$

\section{METODOLOGI PENELITIAN}

Penelitian Adapun penelitian ini termasuk penelitian deskriptif kuantitatif, yaitu suatu prosedur pemecahan masalah yang diselidiki dengan menggambarkan subjek atau objek penelitian (seseorang, lembaga, masyarakat, dan lain-lain) pada saat sekarang berdasarkan fakta-fakta yang tampak atau sebagaimana adanya kemudian menganalisis data yang diperoleh melalui angket dengan menggunakan rumus-rumus statistik. ${ }^{14}$ Maka setelah diperoleh data secara kuantitas (angka) maka penulis mendeskripsikan hasil penelitian dalam bentuk narasi berdasarkan data yang diperoleh.

\section{HASIL PENELITIAN}

Persepsi ini merupakan penelitan kuantitatif dangan tujuan mengidentifikasi kecenderungan yang mempengaruhi minat mahasiswa memilih Program Studi Komunikasi dan Penyiaran terhadap profesi jurnalistik. Pengambilan data menggunakan kusioner dengan 22 butir pernyataan yang menggambarkan minat mahasiswa program studi komunikasi dan penyiaran terhadap profesi jurnalistik. Dalam penelitian ini faktor yang memperngaruhi minat mahasiswa untuk menjadi seorang jurnalistik dibagi menjadi dua yaitu faktor individu dan faktor lingkungan.

12 Asep Saeful Muhtadi, Jurnalistik Pendekatan Teori Dan Praktek, (Jakarta: Logos Wacana Ilmu, 1999), 34.

${ }^{13}$ Masduki, Jurnalistik Radio, (Yogyakarta: LKIS, 2006), 11.

${ }^{14}$ Hadari Nawawi, Metode Penelitian Bidang Sosial, (Yogyakarta: Gajah Mada University Press, 2003), 53. 
Dimana faktor individu memiliki beberapa indikator yaitu keseriusan terhadap profesi jurnalistik, kemauan, sikap dan keaktifan dalam melakukan atau mengikuti perkuliahan jurnalistik di program studi komunikasi dan penyiaran. Sedangkan faktor lingkungan terbagi menjadi tiga indikator yaitu peduli, kesenangan dan intensitas dalam mempelajari atau yang dilakukan. Berdasarkan hasil penelitian dengan 75 mahasisiwa program studi kemunikasi dan penyiaran, dihasilkan data seperti pada tabel 1 berikut.

Tabel 1. Data hasil penelitian faktor yang mempengaruhi kecendenrungan mahasiswa terhadap profesi jurnalis

\begin{tabular}{|c|c|c|c|c|c|}
\hline \multirow{2}{*}{ No } & \multirow{2}{*}{ Faktor } & Indikator & $\begin{array}{c}\text { Jumlah } \\
\text { Butir }\end{array}$ & Mean & Presentase \\
\hline \multirow{3}{*}{1} & \multirow{3}{*}{ Individu } & Keseriusan & 3 butir & 8.79 & $13.63 \%$ \\
\cline { 3 - 6 } & & Kemauan & 3 butir & 7.54 & $13.63 \%$ \\
\cline { 3 - 6 } & & Sikap & 5 butir & 12.45 & $22.72 \%$ \\
\cline { 3 - 6 } & & Keaktifan & 2 butir & 4.07 & $9.09 \%$ \\
\hline \multirow{3}{*}{2} & \multirow{3}{*}{ Lingkungan } & Peduli & 2 butir & 4.07 & $9.09 \%$ \\
\cline { 3 - 6 } & & Kesenangan & 4 butir & 8.16 & $13.63 \%$ \\
\cline { 3 - 6 } & & Intensitas & 3 butir & 7.09 & $13.63 \%$ \\
\hline & & $\mathbf{2 2}$ & $\mathbf{5 2 . 1 7}$ & $\mathbf{1 0 0} \%$ \\
\hline
\end{tabular}

Berdasarkan Tabel 1 diatas menunjukkan bahwa hasil penelitian tentang faktor yang mempengaruhi minat mahasiswa program studi komunikasi dan penyiaran dari faktor individu, dimana faktor individu memiliki empat indikator yaitu keseriusan terhadap profesi jurnalistik memiliki presentase sebesar 13.63\%, dari ketiga butir tersebut memiliki nilai rata-rata sebesar 8.79. Indikator kemauan memiliki presentase sebesar $13.63 \%$, dari ketiga butir tersebut memiliki nilai ratarata sebesar 7.54. Iindikator sikap memiliki nilai presentase sebesar $22.72 \%$ dari kelima butir tersebut memiliki nilai rata-rata sebesar 12.45 dan indikator keaktifan dalam melakukan atau mengikuti perkuliahan jurnalistik di program studi komunikasi dan penyiaran memiliki nilai presentase sebesar $9.09 \%$ dengan dua butir tersebut memiliki nilai rata-rata sebesar 4.07. sehingga hasil perhitungan ini menunjukkan bahwa faktor Individu memiliki presentase sebesar 59.07 dalam mempengaruhi minat mahasiswa Program Studi Komunikasi Dan Penyiaran Islam (KPI) terhadap profesi jurnalis. 
Hasil perhitungan dari kusioner kecenderungan mahasiswa program studi KPI berdasarkan faktor lingkungan dimana faktor lingkungan memiliki tiga indikator yaitu indikator Peduli terhadap perkembangan dan perubahan kondisi dengan 2 butir memiliki nilai rata-rata 4.47 dengan prsentase sebesar $9.09 \%$, Indikator kesenangan terdahap kegiatan profesi jurnalis terdiri dari 3 butir memiliki nilai rata-rata sebesar 8.16 dengan presentase sebesar $13.63 \%$ dan indikator intensitas dalam mempelajari atau yang dilakukan yang terdiri dari 3 butir memiliki nilai rata-rata sebesar 7.08 dengan presentase sebesar 13.63\%. Berdasarkan hasil tersebut secara keseluruhan faktor lingkungan memiliki presentase sebesar $36.35 \%$ dalam mempengaruhi minat mahasiswa program studi KPI terhadap profesi jurnalis.

Secara keseluruhan hasil dari perhitungan ini ditunjukan Gambar 1. pada diagram batang sebagai berikut.

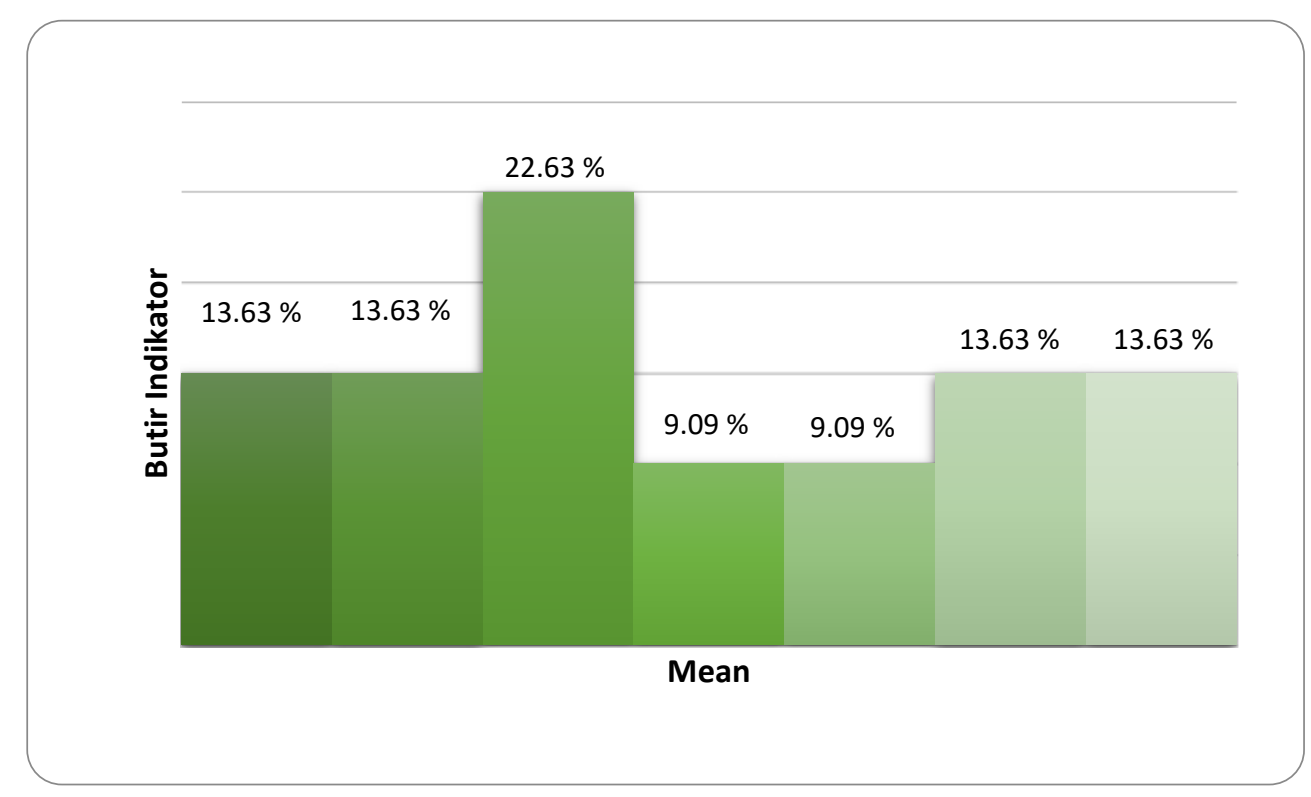

Gambar 1. Keseluruhan Hasil Dari Perhitungan Faktor Individu Dan Lingkungan

Berdasarkan Gambar 1 diagram batang diatas menunjukkan bahwa total keseluruhan hasil penelitian faktor individu (Interpersonal) yang terdiri dari indikator keseriusan terhadap profesi jurnalistik, kemauan, sikap dan keaktifan dalam melakukan atau mengikuti perkuliahan jurnalistik di program studi KPI memiliki jumlah presentase sebesar $59.07 \%$, dari empat indikator tersebut dengan rata-rata jumlah jawaban tiap pernyatan sebanyak 62.96. Sedangkan faktor 
lingkungan yang terdiri dari tiga indikator memiliki presentase sebesar $36.35 \%$ dengan rata-rata jumlah jawaban tiap pernyataan sebesar $37.03 \%$.

Hasil penelitian menunjukkan faktor yang mempengaruhi minat mahasiswa program studi KPI terhadap profesi jurnalis terdiri dari faktor Individu (Interpersonal) dan faktor lingkungan. Faktor individu (Interpersonal) dengan empat indikator yaitu indikator yaitu keseriusan terhadap profesi jurnalistik, kemauan, sikap dan keaktifan dalam melakukan atau mengikuti perkuliahan jurnalistik di program studi komunikasi dan penyiaran Islam dengan keseluruhan berjumlah 13 butir memiliki nilai mean sebesar 61.67, nilai median 62.0, nilai modus 64.0, nilai minimum 54, nilai maksimum 68, standar deviasi 3.47 serta nilai total sebesar 5180. Sehingga apabila digambarkan dalam bentuk histrogram hasilnya seperti ditampilakn pada Gambar 2 berikut.

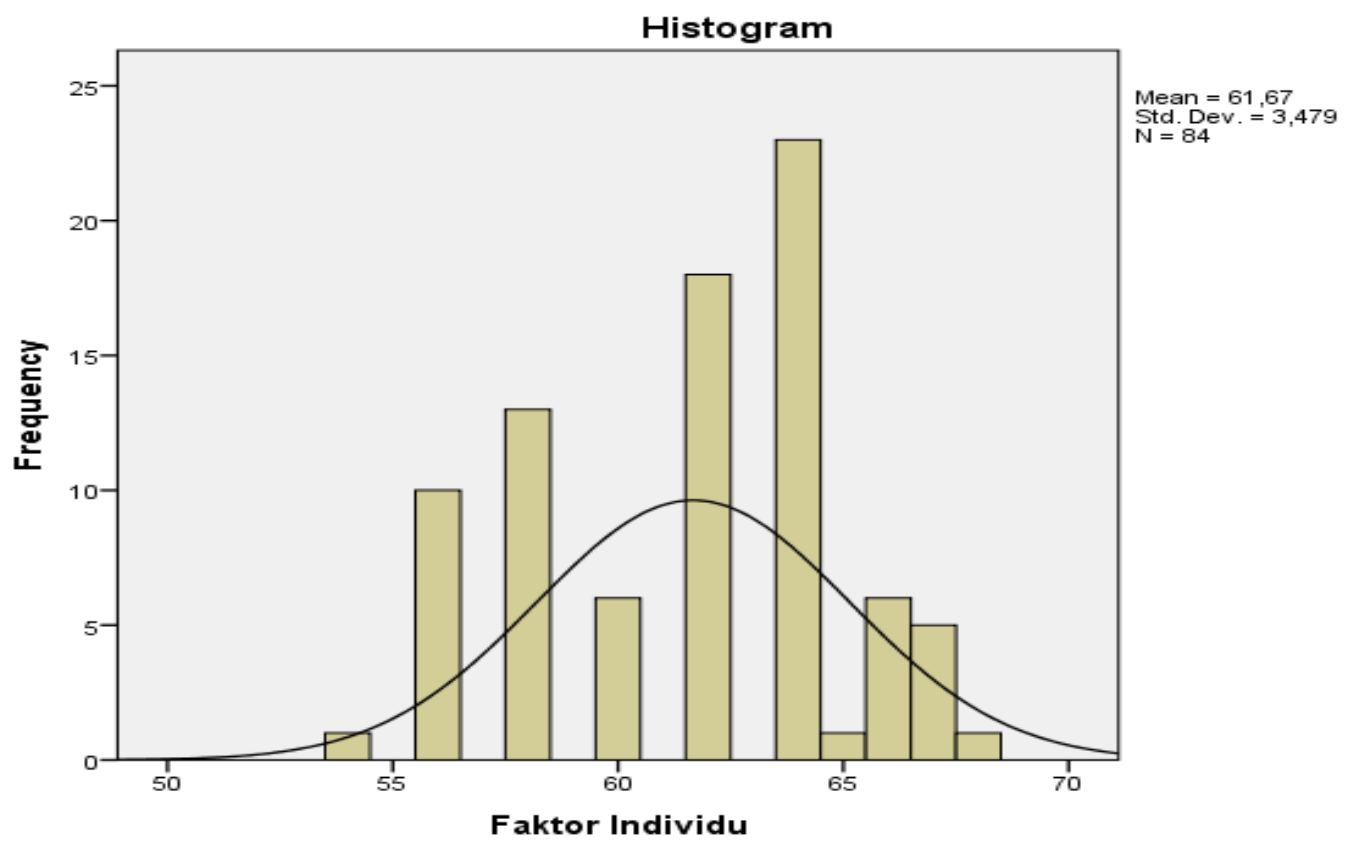

Gambar 2. Bentuk Histiogram Faktor Minat Mahasiswa

Sedangkan faktor lingkungan terbagi menjadi tiga indikator yaitu peduli, kesenangan dan intensitas dalam mempelajari atau yang dilakukan dengan jumlah 9 butir memiliki nilai mean sebesar 34.38, nilai median 34.0, nilai modus 37.0, nilai Minimum 30, nilai maksimum 38, standar deviasi 2.28 serta nilai total sebesar 
2888. Sehingga apabila digambarkan dalam bentuk histrogram hasilnya seperti tampak pada Gambar 3 berikut.

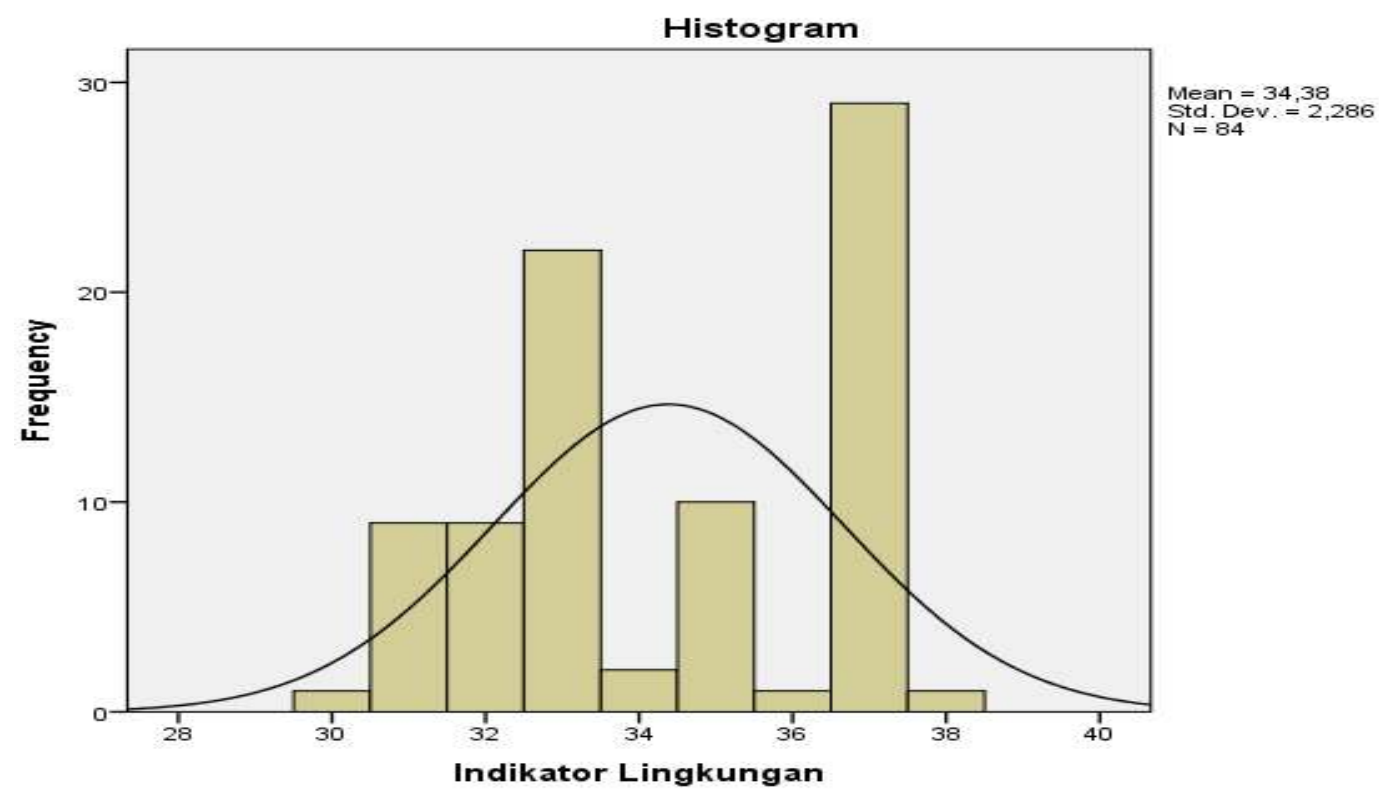

Gambar 3. Minat Berdasarkan Individu.

Hasil penelitian membuktikan bahwa minat berdasarkan faktor individu memiliki andil yang paling tinggi dalam mempengaruhi minat mahasiswa komunikasi dan penyiaran terhadap profesi jurnalistik, lalu faktor lingkungan yang hanya $36.90 \%$ mampu mempengaruhi minat mahasisiwa program studi komunikasi dan penyiaran terhadap minat profesi jurnalistik. Hasil penelitian tentang kecenderungan mahasiswa program studi KPI terhadap profesi jurnalis terdiri dua faktor yaitu faktor individu dan faktor lingkungan. Secara lebih jelas akan di jelaskan per-indikator melalui diagram distribusi.

\section{A. Faktor Individu (Interpersonal)}

1. Keseriusan terhadap profesi jurnalistik

Hasil penelitian menunjukkan bahwa kecenderungan mahasiswa program studi KPI memiliki beberapa faktor yaitu salah satunya faktor individu (Interpersonal) yang terdiri dari empat indikator yaitu Pertama, indikator keseriusan terhadap profesi jurnalistik dimana pada indikator ini mahasiswa lebih mengarahkan perhatian pada hal-hal yang berhubungan profesi jurnalis, setiap mata kuliah yang berhubungan dengan jurnalistik mahasiswa akan selalu memiliki 
tingkat keseriusan yang lebih dari pada mata kuliah lainya. Apabila dijelaskan dari hasil penelitian dihasilkan bahwa indikator keseriusan terhadap profesi jurnalistik memiliki nilai mean sebesar 8.80, nilai median sebesar 9.00, nilai modu sebesar 9, standar deviasi 0.510 , nilai minumun 8 , nilai maksimum 11 serta jumlah total skor adalah sebesar 739. Secara keseluruhan frekuensi data disajikan pada tabel berikut.

Tabel 2. Distribusi Jawaban Kusioner Oleh Responden Terhadap Indikator Keseriusan

\begin{tabular}{cccc}
\hline Interval Skor & F & Persentase & Kategori \\
$9.75-12.0$ & 53 & $97.61 \%$ & Sangat Tinggi \\
$7.5-9.75$ & 31 & $2.38 \%$ & Tinggi \\
$5.25-7.5$ & 0 & $0 \%$ & Sedang \\
$3.0-5.25$ & 0 & $0 \%$ & Sangat Rendah \\
\hline
\end{tabular}

Berdasarkan hasil indikator keseriusan terhadap profesi jurnalistik menunjukkan bahwa hasil bahwa sebesar 97.61\% memperlihatkan mahasiswa memiliki keseriusan terhadap profesi jurnalistik yang menandakan sebesar 53 mahasiswa dari 84 memiliki keseriusan sangat tinggi dibidang profesi jurnalistik. Sedangkan 31 mahasiswa atau sebesar 2.38\% mahasiswa memiliki keseriusan tinggi dibidang profesi jurnalistik. Hasil ini menunjukkan bahwa msecara keseluruhan mahasiswa memiliki keseriusan terhadap profesi jurnalis.

2. Kemauan mahasiswa terhadap profesi jurnalistik

Kemauan mahasiswa program studi KPI terhadap profesi jurnalis ditandai adanya ketertarikan yang ditimbulkan oleh mahasiswa untuk terus mempelajari mata kuliah yang berhubungan dengan jurnalis, dimana setiap adanya mata kuliah yang berhubungan dengan profesi jurnalistik mahasiswa akan selalu memiliki ketertarikan tersendiri sehingga adanya indikator kemauan ini, maka akan diperkuat mahasiswa memiliki minat terhadap profesi jurnalis. Hasil penelitian menunjukkan bahwa indikator kemauan mahasiswa terhadap profesi jurnalistik memiliki nilai mean sebesar 7.55, nilai median sebesar 8.00, nilai modus sebesar 8, standar deviasi 0.684 , nilai minumun 6 , nilai maksimum 8 serta jumlah total skor adalah sebesar 637. Secara keseluruhan frekuensi data disajikan pada tabel berikut. 
Tabel 3. Distribusi Jawaban Kusioner Oleh Responden Terhadap Indikator Kemauan

\begin{tabular}{cccc}
\hline Interval Skor & f & Persentase & Kategori \\
$9.75-12.0$ & 0 & $0 \%$ & Sangat Tinggi \\
$7.5-9.75$ & 56 & $66.66 \%$ & Tinggi \\
$5.25-7.5$ & 28 & $33.33 \%$ & Sedang \\
$3.0-5.25$ & 0 & $0 \%$ & Sangat Rendah \\
\hline
\end{tabular}

Berdasarkan hasil pada Tabel 3 indikator kemauan terhadap profesi jurnalistik menunjukkan bahwa hasil sebesar 66.66\% memperlihatkan mahasiswa memiliki kemauan terhadap profesi jurnalistik yang menandakan sebesar 56 mahasiswa dari 84 memiliki kemauan dibidang pofesi jurnalis dengan kategori tinggi. Sedangkan 28 mahasiswa atau sebesar 33.33\% mahasiswa memiliki kemauan dibidang profesi jurnalistik dengan kategori sedang. Hasil ini menunjukkan bahwa secara keseluruhan mahasiswa memiliki kemauan terhadap profesi jurnalis.

3. Sikap mahasiswa terhadap profesi jurnalis

Ketiga Indikator sikap terhadap profesi jurnalis, dimana mahasiswa yang memiliki minat dan keseriusan untuk menjadi seorang jurnalis akan memiliki sikap bahwa seorang jurnalis adalah seorang yang mampu dan memiliki segudang pengetahuan untuk memberikan informasi yang sedang terjadi, bukan hanya itu seorang jurnalis adalah seorang yang memiliki pengetahuan yang luas, penetahuan yang luas didapat melalui bagaimana selama ini mahasiswa belajar. Sikap ini lah yang dibutuhkan seorang jurnalis dimana akan memperkuat adanya minat pada diri mahasiswa tersebut. Hasil penelitian menunjukkan bahwa indikator sikap mahasiswa terhadap profesi jurnalistik memiliki nilai mean sebesar 12.45 , nilai median sebesar 12.00, nilai modus sebesar 12, standar deviasi 0.897 , nilai minumun 10, nilai maksimum 14 serta jumlah total skor adalah sebesar 1046. Secara keseluruhan frekuensi data disajikan pada tabel berikut.

Tabel 4. Distribusi Jawaban Kusioner Oleh Responden Terhadap Indikator Sikap

\begin{tabular}{cccc}
\hline Interval Skor & f & Persentase & Kategori \\
$16.26-20.0$ & 0 & $0 \%$ & Sangat Tinggi \\
$12.5-[16.25$ & 39 & $46.42 \%$ & Tinggi \\
$8.75-12.5$ & 45 & $53.57 \%$ & Sedang \\
$5.0-[8.75$ & 0 & $0 \%$ & Sangat Rendah \\
\hline
\end{tabular}


Berdasarkan hasil pada Tabel 4 indikator sikap terhadap profesi jurnalistik menunjukkan bahwa hasil sebesar $46.42 \%$ memperlihatkan mahasiswa memiliki sikap terhadap profesi jurnalistik yang menandakan sebesar 39 mahasiswa dari 84 Berdasarkan hasil pada Tabel 7 indikator sikpa terhadap profesi jurnalistik menunjukkan bahwa hasil sebesar $46.42 \%$ memiliki sikap dibidang pofesi jurnalis dengan kategori tinggi. Sedangkan 45 mahasiswa atau sebesar 53.57\% mahasiswa memiliki sikap di bidang profesi jurnalistik dengan kategori sedang. Hasil ini menunjukkan bahwa secara keseluruhan mahasiswa memiliki sikap terhadap profesi jurnalis.

4. Keaktifan mahasiswa

Keaktifan dalam melakukan atau mengikuti perkuliahan jurnalistik di program studi komunikasi dan penyiaran. Keaktifan ini dapat diartikan sebagai kemauan mahasiswa terhadap profesi jurnalistik, namun keaktifan ini lebih dimana mahasiswa selalu mengikuti matakuliah yang berkaitan dengan profesi jurnalis, bukan hanya itu keaktifan mahasiswa dapat timbul dari pergaulan dilungkungan, melalui organisasi dan sebagainya. Hasil penelitian menunjukkan bahwa indikator keaktifan mahasiswa terhadap profesi jurnalistik memiliki nilai mean sebesar 4.07, nilai median sebesar 4.00, nilai modus sebesar 4, standar deviasi 0.404 , nilai minumun 2, nilai maksimum 6 serta jumlah total skor adalah sebesar 342. Secara keseluruhan frekuensi data disajikan pada tabel berikut.

Tabel 5. Distribusi Jawaban Kusioner Oleh Responden Terhadap Indikator Keaktifan

\begin{tabular}{cccc}
\hline Interval Skor & f & Persentase & Kategori \\
$6.5-8.0$ & 0 & $0 \%$ & Sangat Tinggi \\
$5.0-6.5$ & 1 & $1.19 \%$ & Tinggi \\
$3.5-5.0$ & 82 & $97.61 \%$ & Sedang \\
$2.0-3.5$ & 1 & $1.19 \%$ & Sangat Rendah \\
\hline
\end{tabular}

Berdasarkan hasil pada Tabel 5 indikator keaktifan terhadap profesi jurnalistik menunjukkan bahwa hasil sebesar 1.19\% memperlihatkan mahasiswa memiliki keaktifan terhadap profesi jurnalistik yang menandakan hanya 1 mahasiswa dari 84 memiliki keaktifan dibidang pofesi jurnalis dengan kategori tinggi. Sedangkan 82 mahasiswa atau sebesar 97.61\% mahasiswa memiliki 
keaktifan dibidang profesi jurnalistik dengan kategori sedang. Sedangkan sebesar 1.19 yaitu hanya 1 mahasiswa yang memiliki keaktifan bidang profesi dengan kategori sangat rendah.

\section{B. Faktor Lingkungan}

Sedangkan hasil penelitian kecenderungan mahasiswa program studi komunikasi dan penyiaran islam memiliki berdasarkan faktor lingkungan, dimana faktor lingkungan ini memiliki beberapa indikator yaitu salah satunya adalah pertama indikator Peduli terhadap perkembangan dan perubahan kondisi, dalam hal ini mahasiswa selalu berusaha mencari informasi dan selalu ikut andil dalam mengembangkan sebuah informasi yang ia dapat. Kepedulian ini dapat membuat mahasiswa mampu belajar lebih giat dan selalu peduli bukan hanya pada sebuah informasi yang akan dilaporkan melainkan peduli akan lingkungan yang terjadi. Hasil penelitian menunjukkan bahwa indikator kepedulian mahasiswa terhadap profesi jurnalistik memiliki nilai mean sebesar 4.48, nilai median sebesar 4.00, nilai modus sebesar 4, standar deviasi 0.502 , nilai minumun 4, nilai maksimum 5 serta jumlah total skor adalah sebesar 376. Secara keseluruhan frekuensi data disajikan pada tabel berikut.

Tabel 6. Distribusi Jawaban Kusioner Oleh Responden Terhadap Indikator Kepedulian

\begin{tabular}{cccc}
\hline Interval Skor & f & Persentase & Kategori \\
$6.5-8.0$ & 0 & $0 \%$ & Sangat Tinggi \\
$5.0-6.5$ & 0 & $0 \%$ & Tinggi \\
$3.5-5.0$ & 84 & $100 \%$ & Sedang \\
$2.0-3.5$ & 0 & $0 \%$ & Sangat Rendah \\
\hline
\end{tabular}

Berdasarkan hasil pada Tabel 6 indikator kepedulian terhadap profesi jurnalistik menunjukkan bahwa secara keseluruhan mahasiswa yang berjumlah 84 memiliki presentase sebesar $100 \%$ dengan kategori sedang. Hasil ini menunjukkan bahwa secara keseluruhan mahasiswa memiliki kepedulian terhadap profesi jurnalis dalam kategori sedang. Kedua indikator kesenangan terdahap kegiatan profesi jurnalis, dimana dalam indikator ini lebih melihat melalui profesi seorang jurnalis, dimana dalam hal ini menjadi seorang jurnalis bukan hanya mendapat informasiinformasi yang akan membuat kita menjadi kaya pengetahuan, melainkan melalui 
profesi ini mahasiswa akan memiliki pengalaman lebih dimana dapat mengambangkan potensi dirinya menjadi seorang jurnalis yang profesional.

Tabel 7. Distribusi Jawaban Kusioner Oleh Responden Terhadap Indikator Kesenangan

\begin{tabular}{cccc}
\hline Interval Skor & F & Persentase & Kategori \\
$9.75--12.0$ & 0 & $0 \%$ & Sangat Tinggi \\
$7.5-9.75$ & 63 & $75 \%$ & Tinggi \\
$5.25-7.5$ & 21 & $25 \%$ & Sedang \\
$3.0-5.25$ & 0 & $0 \%$ & Sangat Rendah \\
\hline
\end{tabular}

Selanjutnya, hasil penelitian yang menunjukkan pada indikator kesenangan mahasiswa terhadap profesi jurnalistik memiliki nilai mean sebesar 8.17 , nilai median sebesar 8.00, nilai modus sebesar 9, standar deviasi 0.804 , nilai minimun 7 , nilai maksimum 9 serta jumlah total skor adalah sebesar 686. Secara keseluruhan frekuensi data disajikan pada tabel berikut.

Berdasarkan hasil pada Tabel 7 indikator kesenangan terhadap profesi jurnalistik menunjukkan bahwa hasil sebesar 75\% memperlihatkan sebanyak 63 mahasiswa memiliki kesenangan terhadap profesi jurnalistik dengan kategori tinggi. Sedangkan 21 mahasiswa atau sebesar 25\% memiliki kesenangan di bidang profesi jurnalistik dengan kategori sedang.

Serta ketiga, indikator intensitas dalam mempelajari atau yang dilakukan, dimana dalam hal ini seorang mahasiswa akan memiliki kemamuan bukan hanya untuk belajar mengungkap suatu informasi melainkan ia akan belajar untuk melakukan sesuatu yang berguna bukan hanya untuk dirinya melainkan bagi masyarakat luas, belajar dan melakukan adalah hal sangat sangat penting bagi seorang jurnalis. Hasil penelitian menunjukkan bahwa indikator itensitas mahasiswa terhadap profesi jurnalistik memiliki nilai mean sebesar 7.10, nilai median sebesar 7.00, nilai modus sebesar 7, standar deviasi 0.481 , nilai minumun 5, nilai maksimum 9 serta jumlah total skor adalah sebesar 596. Secara keseluruhan frekuensi data disajikan pada tabel berikut.

Tabel 8. Distribusi Jawaban Kusioner Oleh Responden Terhadap Indikator Intensitas

\begin{tabular}{cccc} 
Interval Skor & F & Persentase & Kategori \\
$9.75-12.0$ & 0 & $0 \%$ & Sangat Tinggi \\
$7.5-9.75$ & 11 & $13.09 \%$ & Tinggi \\
$5.25-7.5$ & 71 & $84.52 \%$ & Sedang \\
$3.0-5.25$ & 1 & $1.19 \%$ & Sangat Rendah \\
\hline
\end{tabular}


Berdasarkan hasil pada Tabel 8 indikator intensitas terhadap profesi jurnalistik menunjukkan bahwa hasil sebesar 13.09\% memperlihatkan sebanyak 11 mahasiswa memiliki intensitas terhadap profesi jurnalistik dengan kategori tinggi. Sedangkan 71 mahasiswa atau sebesar $84.52 \%$ memiliki minat intensitas di bidang profesi jurnalistik dengan kategori sedang. Sedangkan 1.19\% yaitu 1 mahasiswa memiliki minat intensitas di bidang profesi jurnalistik dengan kategori rendah.

\section{KESIMPULAN}

Berdasarakan hasil penelitian, dapat disimpulkan bahwa menghasilkan faktor yang mempengaruhi kecenderungan mahasiswa program studi Komunikasi dan Penyiaran Islam terhadap profesi Jurnalis, terdapat faktor individu (Interpersonal) yang terdiri dari empat indikator yaitu indikator keseriusan terhadap profesi jurnalistik, kemauan, sikap dan keaktifan dalam melakukan atau mengikuti perkuliahan jurnalistik di program studi komunikasi dan penyiaran memiliki jumlah presentase sebesar 59.07\%, dari empat indikator tersebut dengan rata-rata jumlah jawaban tiap pernyatan sebanyak 62.96. Sedangkan faktor lingkungan terbagi menjadi tiga indikator yaitu Peduli, kesenangan dan intensitas dalam mempelajari atau yang dilakukan. memiliki presentase sebesar $36.35 \%$ dengan ratarata jumlah jawaban tiap pernyataan sebesar 37.03.

\section{DAFTAR PUSTAKA}

Astari, Asti Dewi. Skripsi Minat Menjadi Jurnalis Pada Mahasiswa Komunikasi Dan Penyiaran Islam Fakultas Dakwah UIN Sunan Kalijaga Yogyakarta, http://digilib.uin-suka.ac.id.Pdf diakses pada 27 Februari 2016.

Maisaroh, Siti. Pengaruh Minat Mahasiwi Fakultas Ilmu Pendidikan Universitas Negeri Medan Terhadap Kegiatan Dakwah Muslimah Hizbut Tahrir, Skripsi: Universitas Negeri Medan (UNIMED), 2011.

Manan, Abdul. Upah Layak Jurnalis, Survey Upah Layak AJI di 16 Kota di Indonesia, Jakarta: Aliansi Jurnalis Independen (AJI) Indonesia, 2011.

Masduki, Jurnalistik Radio, Yogyakarta: Lkis, 2006.

Mufid, Muhammad, Komunikasi Regulasi Dan Penyiaran, Jakarta: Kencana, 2007.

Muhtadi, Asep Saeful. Jurnalistik Pendekatan Teori Dan Praktek, (Jakarta: Logos Wacana Ilmu,1999. 
Nawawi, Hadari. Metodologi Penelitian Sosial, Yogyakarta: Gajah Mada University Press, 2003.

Saeful Muhtadi, Asep, Jurnalistik Pendekatan Teori dan Ptaktik, Jakarta: Logos Wacana Ilmu, 1999.

Shaleh, Muhbib Rahman, Abdul Wahab, Psikologi Suatu Pengantar Dalam Perspektif Islam, Jakarta: Kencana, 2004.

Stein, M.L, Bagaimana Menjadi Wartawan, Jakarta: Rineka Cipta, 1993.

Sunarjo, Djoenasih S. Pengantar Ilmu Komunikasi, Jakarta: Liberty, 2000.

Syamsir, Salam dan Jaenal Arifin, Metodologi Penelitian Sosial, Jakarta: UIN Jak Press, 2006.

Syamsul M. Romli, Asep. Jurnalistik Praktis, Bandung: Remaja Rosdakarya, 2005.

Winurantho, Masih Bertumpu Pada Sang Pelopor, Survei Serikat Pekerja di Perusahaan Media, Jakarta: Aliansi Jurnalis Independen Indonesia, 2010. 